\title{
An Empirical Investigation on the Role of exports, imports and it's Determinants in Foreign Trade of
} Pakistan

\author{
Gulzar Ali, Zhaohua Li \\ Huazhong University of Science \& Technology, Wuhan, Hubei, P.R. China \\ gulzaricup@yahoo.com
}

\begin{abstract}
Foreign trade was restrained by fluctuations and depreciations in currencies, nations were under financial pressure to implement protection measures in form of custom duties tariffs. These theories and thoughts have enormous impact on rules and policies of global trade throughout the world. To adopt economic liberalization and free trade zones nations all over the world are connected through number of agreements since last few centuries. In this revolutionized economic system, nations allow free trading of merchandise and services and at the same time don't have to impose tariff in form of import and exports duties. This study attempted to empirically evaluate the role of imports, exports and its determinants in foreign trade of Pakistan applied ARDL Approach for the period of 1972-2015. The study recommends that economies with significant competitiveness and comparative advantage will be greatly benefited from export promoting policies. As far as trade partners are concerned, no considerable efforts have been done to explore new markets in direction of Pakistan's foreign trade since its independence. The key trading partners of Pakistan in the beginning were the developed countries of West and still they are main trading partners of Pakistan.
\end{abstract}

Keywords: Foreign Trade, Imports, Exports, ARDL Approach and Stability Analysis.

\section{Introduction}

Trade being too old phenomena initiated from barter system replaced with Mercantilism. With publication of Adam Smith's "The Wealth of Nations" in 18 $18^{\text {th }}$ century trade transferred to liberalism emphasis on the absolute advantage from trade in form of product specialization on large scale. In early twentieth century Heckscher and Bertil Ohlin ( $\mathrm{H}-\mathrm{O}$ model) designed the theory of international trade that nations will manufacture and export commodities which can be produced efficiently by using factors of production or raw material which are comparatively abundant in that country and import the rest which are produced with relatively scarce resources. Generally the theory sounds accurate but practical deficiency in the H-O model was discovered by Wassily Leontief known as Leontief paradox which identified that the United States has a tendency to export labor-abundant commodities regardless of having capital abundance. One of new developments in international trade theories is Gravity model of trade which shows a deep practical scrutiny of trade patterns, it estimates trade on the basis of distance among nations and the monetary value or size of the economy of trading partners.

Trade is an ancient practice pertaining to be a natural phenomenon to attain different desires since decades of human history. Throughout history, the most perceptible change in trade is its range and dimension. The main reason behind trade is lake of self-sufficiency of economic agents and countries; no nation has sufficient resources to achieve all the demands of its inhabitants. So the country enriches in physical, capital or natural resources will produce the commodities with comparatively efficient productivity and exchange these products with rest of the world for commodities in which it has comparative disadvantage. Factor endowment, climate or natural resources, population, taste and technological changes greatly influenced the capacity of international trade and global markets. Pakistan is facing a persistent trade deficit since its initiation because of poor economic performance and lake of infrastructural facilities. Exports of Pakistan consists of low value added and raw or semi-processed agricultural-products. In 1950-60 Pakistan adopted the policy of import substitution to stabilize and protect domestic industries and increase its share in manufactured products. National demand was shifted from foreign products to goods produced domestically through protecting industries from foreign competition. Consequently some important industrial units were developed due to these policies and economy observed phenomenal growth in 1960's; in short at that time these policies proved to be instrumental in industrial establishment and development.

Most of the economic policies are generalized but still most of these have different effects on different economies under various socio-economic circumstances. Similarly where protectionist policies in form of 
import substitution worked in favor of industrialization of Pakistan for other developing economies it wasn't that effective therefore they adopted export promotion policies instead and succeeded in attaining phenomenal economic growth. In mid 1970's Pakistan under inspiration from the economic development of these economies attracted towards adopting trade liberalization policies, still till late 1990 Pakistan stick to protectionists policy regarding foreign trade. Where these protective policies had positive impact in form of new industries at the same time these policies decreased the standards and levels of competition in food and textile industries. The significance of foreign trade in emerging economies becomes a core issue now-a-days, that's why the subject matter of this study is profoundly debated these days and gets a lot of interest especially in the new industrial and developing countries. Pakistan is persistently facing a huge trade deficit as well as low economic growth. In order to minimize trade deficit and to enhance a steady growth rate needs a profound investigation.

This research study will be aiming to find out the answer of these questions that, is there any momentous effect of imports and exports on foreign trade of Pakistan? Whether Trade liberalization policy is assistance or hindrance in favorable balance trade of Pakistan? Different international economic policies affect world economies in a different way according to their economic and financial conditions, culture and socioeconomic setup, climate and environment etc; hence this research study emphasizes on the effect of foreign trade policy on Pakistan's economy. Does exports, imports and international trade helps to reduce the trade deficit and improve the Pakistan's economic growth as Pakistan facing persistently trade deficit since independence and low economic growth from last decades. To examine detailed scrutiny of sectoral imports and exports and its impact on international trade; each economic sector is observed with respect to its importance for aforementioned. Furthermore main variables were decomposed in secondary variables to have detailed insightful of possible effect, outcome and nature of variables in more detail. In short the researcher is aiming to have accurate and comprehensive results.

\section{Literature Review}

Foreign trade, exports and imports has dual role in the economy. Firstly, it affects directly Balance of Payment ${ }^{1}$ in the short-run creating sever fluctuation the current account balances. Secondly, through BOP it also affects the GNP ${ }^{2}$ or National Income ${ }^{3}$ of a country in the long-run. International trade is the most volatile component of GNP and having close relation with economic growth of a country. It has also a strong impact on the aggregate supply and aggregate demand of goods and services on any country. It is simple to find the role of exports in international trade, but very sensitive to find out the role of imports in international trade. Ahmed (2000) investigated the response of Bangladesh's exports towards its Trade Liberalization and Economic Growth applying Co-Integration and Error Correction Model (ECM). The results of the study found long-run relation among exports of goods, price of exported goods, exchange rate and trade liberalization having significant effect on the economic growth of Bangladesh for the period of 1994-19995. However, the study found short-run relation between supplies of exported goods and Bangladesh's economic growth. Yanikkaya (2003) examined the impact of trade liberalization on export, import, net export and economic growth, selecting 120 countries. Panel data were used in the study for the period of 1970 to 1977 . The variables were regressed through Generalized Method of Movement (GMM). The results revealed that these variables have significant with positive sign, indicating the major role of these variables in economic growth.

Martinez-Zarzoso and Nowak-Lehmann (2003) examined the bilateral annual exports among the 19 countries. The study used panel data for the period of analysis from 1975 to 2002. The trade Gravity Model was applied in the methodology to find out the impact of bilateral exports on population growth rate, infrastructures and imports of these 19 countries. The study found the positive and significant effect of exports on both population and infrastructures on the economic growth of these selected samples of study countries. The study also found that bigger population countries have greater imports as compared to small

\footnotetext{
${ }^{1}$ BOP is define as "The annual record of all economic transaction of one country with other countries OR the annual record of all economic transaction of a resident country with rest of the world during one year". It has three basic Accounts; Current Account, Capital Account \& Reserved or Official Settlement Account.

2 Gross Domestic Product (GNP) defined as "The total market value of final goods and services produced by a country during a year".

${ }^{3}$ Simplest definition is "the total outcome of country is called National Income".
} 
population countries. Further, the study concluded that infrastructure too played a leading role like exports in raising the economic growth of these sample selected countries. Akhtar (2003) investigated the seasonal behavior and pattern of Pakistan's exports and imports using quarterly data from 1984: 1 to 2002:1. In the methodology several techniques like integrated models, Auto-Regressive Integrated Model Analysis (ARIMA), mixed ARIMA, ARIMA-GARCH and unit root test. Though the study used diverse and varied analytical techniques, found that the deterministic effect of both exports and imports were relatively stronger than stochastic effects. Akhtar and Ghani (2010) studied free trade agreement benefits for SAARC countries applying trade gravity model. The study found constructive and assenting effect of trade agreements on economic growth of SAARC countries for the period of 2003-2008, using cross-sectional.

Filippini and Molini (2003) attempted to determine the trade flows between industrializing countries, East Asian countries including China and with some other developed countries. The study used panel data covering the period of analysis from 1970 to 2002. In the methodology of the study the Trade Gravity Model was applied to examine the impact of bilateral trade flows among the industrializing, East Asian and developed countries. The study found the positive and significant impact with true expected signs of the entire hypothesis to be tested and for estimator too. Further, the study also found that China played a dual important and significant role as an exporter and importer too, showing the bursting getting of advantage from bilateral trade. Ahmad, Alam and Butt (2004) examined the causal relationship between exports, imports, Foreign Direct Investment (FDI), domestic production, Domestic Output, trade openness and economic growth of Pakistan applying Johansen Co-integration, Vector Auto Regressive (VAR) model and Granger Causality test. The study found the causal relation among the included variables, i.e. Exports, Manufacturing Production, Domestic Output, Foreign Direct Investment (FDI), Foreign Income and exchange rate as well as of these variables with economic growth of Pakistan for the period of 1972-2001. Iacovoiu (2013) analyzed the impact of exports, imports and capital formation on the economic growth of Romania. The study used time series data for the period of 2004-2012. In the methodology they used co-integration vector analysis, multivariate co-integration, Vector Auto-regressive (VAR) model and Error Correction Model (ECM). The results revealed that exports, imports and capital formation have positive and significant on the economic growth of Romania.

Santos-Paulino and Thirlwall (2004) examined the impact of trade liberalization policies on the balance of payment, export, balance of trade and import. They used mixed data including panel, time-series and crosssectional data. The study was analyzed for those twenty-two developing countries have adopted trade liberalization policies in 1970's. The results showed that both export and import of these developing countries increase by adopting the liberalization policies. It was also evident from the results that increase in imports was much higher than export of these countries producing fluctuation and instability both in balance of payment and balance of trade, alternatively slowdowns the growth of the economies and also effect the living standard and output of these countries. Achay (2006) studied the trade flows among different countries of the world. The study used panel data for the five sub-periods on yearly basis from 1970 to 2000. In the methodology of the study the Trade Gravity Model was applied to find out the trade flows relationship between 126 different countries of the world. The results obtained from the study revealed that bilateral trade flows have positive and significant impact for these 126 selected sample countries with each other taking the momentous increase in their economic growth from bilateral trade. Awokuse (2007) examined the impact of exports and imports on economic growth for Czech Republic, Bulgaria and Poland. The panel data were used in the study for the period of analysis from 1980 to 2006. In the methodological framework used the error correction model. The results captured the bi-directional causal relation between exports, imports and economic growth for Bulgaria. For Czech Republic unidirectional causality relation from exports and imports are captured, while only imports led-growth were found for Poland.

Zaman et al. (2010) attempted to empirically examine the bilateral trade impact between Pakistan and Turkey. The panel data was used in the study covering the period of analysis from 1990 to 2008. In the methodology they applied the Trade Gravity Model to explore the bilateral trade flows between Pakistan and Turkey. The results obtained from the regression analysis of the study showed the strong relationships between bilateral trade flows and economic growth for both Pakistan and Turkey and weak relationship between distance of these two countries and bilateral trade flows. In the recommendations of the study they suggested that bilateral trade between these two countries needs more boost up and upgrading for achieving 
the prosperous economic growth. Emeka, Fredrick and Peter (2012) studied the impact of export and international trade on Nigeria's economy by developing the combination of multi-variant and bi-variant models of macroeconomic variables. They used time series data covering the period from 1970 to 2008 . The results revealed that foreign direct investment and export have significant positive sign, showing their important effect on Nigeria's economy. In the policy recommendation they suggested that there should be connection between the fiscal policy and export to achieve the desired goal for Nigeria's economy. Javed et al. (2012) analyzed the impact of international trade, exports, imports, investments and trade openness on the economic growth of Pakistan. They used time-series data for the period of 1973 to 2010. In the methodology they used Chow Test and regressed through simple Ordinary Least Square (OLS) method. The study revealed that these variables effect the short-run growth of Pakistan economy more significantly as compared to longrun. Further, the imports of some goods bring increase in the production in Pakistan resulting more output and employment.

Sulaiman and Hussain (2012) empirically investigated the impact of exports, imports, Foreign Direct Investment (FDI) and trade openness on economic growth of Pakistan. The annual time series data was used in the study covering the period of analysis from 1970 to 2012. In methodology of the study they used Johnson co-integration technique and Error Correction Model (ECM) for the estimation and regression of variables. The results revealed that there is positive and significant impact of trade openness on economic growth of Pakistan in long run having major role of Foreign Direct Investment (FDI) too. Further, the study concluded that in Pakistan the growth mainly are export led growths (ELG). In policy recommendation they suggested that government of Pakistan should need to focus on the export by improving their quality, quantity, marketing of products and access of domestic exporter in to foreign market. Azeez, Dada and Aluko (2014) studied the impact of international trade, exports, imports and trade openness on economic growth of Nigeria. The annual time series data for the period of 2000-2014 was used and regressed through simple Ordinary Least Square (OLS) technique. The results obtained from the regression analysis revealed that international trade, export and imports had significant impact on Nigeria's Economy. The study suggested that government should need to decrease dependency from oil export products and bring increase in the exports of non-oil products.

\section{Econometric Model and Description of Data}

This research study observing the evolution of embodied exports and imports of goods in international trade and afterward on the economic growth of Pakistan. For this, the econometric model for the growth of exports, imports, its determinants and international trade of the country was developed. The basic idea for the development of the theoretical and econometric models have been taken from previous models used by Santos-Paulino and Thirlwall (2004), Wacziarg and Welch (2003). Ju et el. (2010) extended their work to develop models for this study. The demand for goods in the international market (international trade) depends on the assessment of the comparative prices of goods, the relative prices of the currencies of both the trading countries and demand for goods in the world countries and in international market. If the world income, the elasticity of world income and the proportional price of the goods in the world countries assume as constant than the international trade equation are expressed as;

$$
I . T_{t}=A\left(X_{t}\right)^{\alpha_{1}}\left(M_{t}\right)^{\alpha_{2}}\left(Y_{t}\right)^{\alpha_{3}}\left(E R_{t}\right)^{\alpha_{4}}
$$

Here, small " $t$ " represents the time period (time series), I. $T_{t}$ is the international trade, $X_{t}$ is the exports, $M_{t}$ is the Imports, $\mathrm{Y}_{\mathrm{t}}$ is the World Income take as constant and $\mathrm{ER}_{\mathrm{t}}$ is the exchange rate in time period " $\mathrm{t}$ ".

In equation (3.1) $\alpha_{1}$ is the price elasticity of demand for exporting goods, $\alpha_{2}$ is the price elasticity of demand for Importing goods, $\alpha_{3}$ is the Income elasticity of demand for both exports and imports goods and $\alpha_{4}$ is the price elasticity of exports and imports from Country "i" to country " $\mathrm{j}$ ". In other words $\alpha_{4}$ is the price elasticity in relative currencies of both countries. To formulate the equation (3.1) to linear form, the logarithmic is taken on both side of the equation (3.1).

$$
\operatorname{Ln}\left(I . T_{t}\right)=\operatorname{Ln}(A)+\alpha_{1} \operatorname{Ln}\left(X_{t}\right)+\alpha_{2} \operatorname{Ln}\left(M_{t}\right)+\alpha_{3} \operatorname{Ln}\left(Y_{t}\right)+\alpha_{4} \operatorname{Ln}\left(E R_{t}\right)
$$


Now, by taking the derivative on both side of the equation (3.2), with respect to time " $\mathrm{t}$ " the growth rate in international trade with respect to exports, imports, world income and exchange rate be determine. The equation (3.2) will become as follows;

$$
\left(\dot{I . T_{t}} / I . T_{t}\right)=(\dot{A} / A)+\alpha_{1}\left(\dot{X}_{t} / X_{t}\right)+\alpha_{2}\left(\dot{M}_{t} / M_{t}\right)+\alpha_{3}\left(\dot{Y}_{t} / Y_{t}\right)+\alpha_{4}\left(\dot{E R}_{t} / E R_{t}\right)
$$

In the econometric form for the empirical regression the equation (3.3) be articulated as

$$
I T_{t}=\alpha_{0}+\alpha_{1} x_{t}+\alpha_{2} m_{t}+\alpha_{3} y_{t}+\alpha_{4} e r_{t}+\mu_{t}
$$

In the above equation (3.4), IT $\mathrm{T}_{\mathrm{t}}\left(=\mathrm{I} \cdot \mathrm{T}_{\mathrm{t}}^{*} / \mathrm{I} \cdot \mathrm{T}_{\mathrm{t}}\right), \mathrm{x}_{\mathrm{t}}\left(=\mathrm{X}_{\mathrm{t}}^{*} / \mathrm{X}_{\mathrm{t}}\right), \mathrm{m}\left(\mathrm{M}_{\mathrm{t}}^{*} / \mathrm{M}_{\mathrm{t}}\right), \mathrm{y}_{\mathrm{t}}\left(=\mathrm{Y}_{\mathrm{t}}^{*} / \mathrm{Y}_{\mathrm{t}}\right)$ and $\mathrm{er}_{\mathrm{t}}\left(=\mathrm{ER}_{\mathrm{t}}^{*} / \mathrm{ER}_{\mathrm{t}}\right) . \alpha_{0}\left(=\mathrm{A}^{*} / \mathrm{A}\right)$ and taken as constant i.e. technology, shocks etc. $\alpha_{1}$ and $\alpha_{2}$ are the price elasticity of demand for exports and Imports of goods, $\alpha_{3}$ is the Income elasticity of demand for both exports and imports goods and $\alpha_{4}$ is the price elasticity of trading goods in relative currencies for both the countries. $\mu$ t is the error term or the white noise error stochastic term. The random error term is assumed to be normally distributed through the subsequent restrictions, $\quad\left[E\left(\eta_{i}\right)=0\right],\left[E\left(\eta_{i}\right)^{2}=\sigma^{2}\right],\left[E\left(\eta_{i}, \eta_{j}\right)=0\right]$

This process is known "White noise process".

The basic motive and reason for international trade among the countries is quite simple. Some countries can produce more goods as compared to other countries and they have comparative advantage of producing these goods over other nations having more resources, efficient allocation, modern technology, enhanced capital and low production cost. Some countries have economically better than other countries in producing the goods that are excessive than there domestic consumption. The rational for international trade follows that the countries producing auxiliary goods from their domestic consumption needs, Countries can exports those goods to other countries while imports those goods from other countries in which they have deficiency in satisfying their domestic needs and requirements. The international trade is one of the important components of GDP especially for the countries have adopted policy of an open economy. The international trade is depended on the exports and import of country. Greater the exports and less imports brings surplus and less exports and greater imports cause deficit in the balance of trade for the resident country. In keeping the importance of international trade in view, Pakistan has made several attempts by adopting liberalization policies of trade openness to gain more fruit from international trade.

To investigate the broader impact of Pakistan's exports and imports on the international trade of Pakistan, the parent model developed for the international trade growth is followed. It is expected that the model derived to estimate the broader effect of exports and imports on international trade from the basic model (3.4) are truly be envoy of explaining the behavior of export and import in international trade of Pakistan. The dependent variable is the international trade (IT) while the independent variables are exports (X), Imports (M), exports of primary commodities (XPC), exports of textile manufacturing sector (XTM), exports of other manufacturing sector (XOM), export of other commodities and goods(XO), imports of food products (MFP), imports of Heavy Machinery (MHM), Imports of petroleum products (MPP), imports of textile and metals (MTM), imports of agriculture products and their chemicals (Magri), imports of other goods (MOP), world income $(\mathrm{Y})$, exchange rate (ER), tariff imposition on export(TRFx), tariff imposition on imports (TRF ${ }^{\mathrm{M}}$ ), Dummy variable for Trade openness or Liberalization policy (TOP), terms of trade (TOT) and balance of trade (BOT). The theoretical equation that expressed the relationship between dependent and independent variables is expressed as;

$\mathrm{IT}=\mathrm{f}(\mathrm{X}, \mathrm{M}, \mathrm{XPC}, \mathrm{XTM}, \mathrm{XOM}, \mathrm{XO}, \mathrm{MFP}, \mathrm{MHM}, \mathrm{MPP}, \mathrm{MTM}$,

Magri, MOP, Y, ER, TRFx, TRFM ${ }^{\mathrm{M}}$, TOP, TOT, BOT)

The econometric model of the above equation (3.5) can be formed as follows;

$$
\begin{aligned}
& I T_{t}=\left(\gamma_{0}+\gamma_{1} X_{t}+\gamma_{2} M_{t}+\gamma_{3} X P C_{t}+\gamma_{4} X T M_{t}+\gamma_{5} X O M_{t}+\gamma_{6} X O_{t}+\gamma_{7} M F P_{t}+\gamma_{8} M H M_{t}\right. \\
& +\gamma_{9} M P_{t}+\gamma_{10} \text { MTM }_{t}+\gamma_{11} \text { MAgri }_{t}+\gamma_{12} \text { MOP }_{t}+\gamma_{13} Y_{t}+\gamma_{14} E R_{t}+\gamma_{15} \text { TRF }_{t}^{x}+\gamma_{16} \text { TRF }_{t}^{m} \\
& \left.+\gamma_{17} T O P_{t}+\gamma_{18} T O T_{t}+\gamma_{19} B O T_{t}+\mu_{t}\right) \text {. }
\end{aligned}
$$

The sign of the coefficient/ estimator are expected as;

$$
\begin{aligned}
& \gamma_{1}>0, \gamma_{2}>0, \gamma_{3}>0, \gamma_{4}>0, \gamma_{5}>0, \gamma_{6}>0, \gamma_{7}>0, \gamma_{8}>0, \gamma_{9}>0, \gamma_{10}>0, \\
& \gamma_{11}>0, \gamma_{12}>0, \gamma_{13}>0, \gamma_{14}>0, \gamma_{15}<0, \gamma_{16}>0, \gamma_{17}>0, \gamma_{18}<0, \gamma_{19}>0,
\end{aligned}
$$


Data Analysis and Sources: The data used in this study are the annual time series data, because quarterly and semi-annual data are not available for most of the variables included in the study in their desired form. The time periods of analysis are from 1972 to 2015. Prior to 1972, due to the conflicts of different policies and separation of East-Pakistan the data for the selected variables in this research study are unavailable in their purified and true form. The data used in this study are obtained from Economic Surveys, Federal Bureau of Statistics, State Bank of Pakistan, Agriculture Development Bank of Pakistan (ZTBL), Cooperatives and Commercial Banks, International Financial Statistics (IFS), Pakistan Institute of Development Economics (PIDE), World Development Report (WDR), National Accounts of Pakistan, Federal Board of Revenue (FBR) Pakistan, Custom House (Islamabad) Pakistan, World Development Index, World Bank, Trading Economics, World Economic data Indicator, Global Economy, Ministry of Finance Pakistan, Economic Affairs Division Pakistan, World Trade Organization (WTO) Statistics Database, from different surveys and reports.

\section{Methodology, Results and Discussion (Regression Analysis of Model)}

In time series analysis there is always worried and apprehension about spurious relationship. As the current research study is also based on time series analysis, therefore before running an appropriate regression technique the variable data has tested for unit root by applying Augmented-Dicky Fuller (ADF) test. initially, the ADF test is applied at level $\{\mathrm{I}(0)\}$ on all the variables data and the results integrated in table (1) indicates that some variables are stationary at level, while some variables has unit root accepting $\mathrm{H}_{0}$ for some variables). Therefore, going ahead we applied ADF test on first difference also and outcome reveals that some variables are stationary at I(0) and some are at I(1). As none of the variables is integrated of order two or $\mathrm{I}(2)$, that confirm that there isn't any spurious relationship among the variables in the observed data. When some variables are stationary at me(0) and some are at I(1), Auto-Regressive Distributed Lag (ARDL) model is suggested by economist and researchers for regression analysis of the variables data.

Table: 1 Augmented Dickey-Fuller Unit Root Test Results

\begin{tabular}{|c|c|c|c|c|}
\hline \multirow[t]{2}{*}{ Variables } & \multirow[t]{2}{*}{ Acronyms } & \multicolumn{2}{|l|}{ ADF Values } & \multirow[t]{2}{*}{ ADF Critical Values } \\
\hline & & At Level & At $1^{\text {st }}$ Difference & \\
\hline International Trade & IT & -1.270626 & $-3.528793^{*}$ & -2.9378 \\
\hline Exports & $\mathrm{X}$ & $-2.465024 * *$ & $-3.780645^{*}$ & -2.9378 \\
\hline Imports & M & -1.468560 & $-3.954462 *$ & -2.9378 \\
\hline Exports of Primary Commodities & XPC & $-2.888938^{* *}$ & $-3.474630^{*}$ & -2.9378 \\
\hline $\begin{array}{l}\text { Exports of Textile Manufacturing } \\
\text { Sector }\end{array}$ & XTM & $-3.338658^{*}$ & $-3.028298^{*}$ & -2.9378 \\
\hline $\begin{array}{l}\text { Exports of Other Manufacturing } \\
\text { Sector }\end{array}$ & XOM & -0.933170 & $-4.130593^{*}$ & -2.9378 \\
\hline Exports of Other goods & XO & $-2.935485^{*}$ & $-4.473913^{*}$ & -2.9378 \\
\hline Imports of food products & MFP & -1.086570 & $-3.892350 *$ & -2.9378 \\
\hline Imports of Heavy Machinery & MHM & $-3.248487^{*}$ & $-4.289952^{*}$ & -2.9378 \\
\hline Imports of petroleum products & MPP & $-3.534812^{*}$ & $-4.973725^{*}$ & -2.9378 \\
\hline Imports of textile and metals & MTM & $-2.678600 * *$ & $-5.073726^{*}$ & -2.9378 \\
\hline $\begin{array}{l}\text { Imports of agriculture products } \\
\text { and chemicals }\end{array}$ & MAgri & -1.992232 & $-3.823919^{*}$ & -2.9378 \\
\hline Imports of other goods & MOP & -2.159266 & $-6.724687 *$ & -2.9378 \\
\hline Export Tariffs & $\mathrm{TRF}^{\mathrm{x}}$ & $-3.580181^{*}$ & $-4.989223^{*}$ & -2.9378 \\
\hline Import duties & $\mathrm{TRF}^{\mathrm{M}}$ & -1.520033 & $-4.141358^{*}$ & -2.9378 \\
\hline World Income & Y & $-2.698155^{* *}$ & $-3.795314^{*}$ & -2.9378 \\
\hline Exchange Rate & ER & -1.488565 & $-3.647880^{*}$ & -2.9378 \\
\hline Trade Openness & TOP & -0.820238 & $-5.071277^{*}$ & -2.9378 \\
\hline Terms of Trade & TOT & -1.936422 & $-5.784582 *$ & -2.9378 \\
\hline Balance of Trade & BOT & $-4.858152 *$ & $-6.485582 *$ & -2.9378 \\
\hline
\end{tabular}

Critical Value of ADF is selected at $5 \%$ significance level. $(*) \&(* *)$ shows rejection of Null Hypothesis at $5 \%$ \& $10 \%$. 
To empirically evaluate the importance of exports, imports and its determinants in Pakistan's foreign trade, the Auto-Regressive Distributed Lag (ARDL) model is applied. The dependent variable is international trade (IT) and the independent variables are Exports (X), Imports (M), exports of primary commodities (XPC), exports of textile manufacturing sector (XTM), exports of other manufacturing sector (XOM), exports of other commodities and goods (XO), imports of food products (MFP), imports of Heavy Machinery (MHM), Imports of petroleum products (MPP), imports of textile and metals (MTM), imports of agriculture products and their chemicals (Magri), imports of other goods (MOP), world income (Y), exchange rate (ER), tariff imposition on exports (TRFx), tariff imposition on exports (TRFM),Proxy variable for Trade openness or Liberalization policy (TOP), terms of trade (TOT) and balance of trade (BOT). The theoretical equation to express the relationship between dependent and independent variables is articulated as;

IT = $\mathrm{f}(\mathrm{X}, \mathrm{M}, \mathrm{XPC}, \mathrm{XTM}, \mathrm{XOM}, \mathrm{XO}, \mathrm{MFP}, \mathrm{MHM}, \mathrm{MPP}, \mathrm{MTM}$, Magri, MOP,Y, ER, TRFx, TRFm, TOP, TOT, BOT) (4.1)

The econometric model of the above theoretical equation (4.1) can be formed as follows;

$$
\begin{aligned}
& I T_{t}=\left(\gamma_{0}+\gamma_{1} X_{t}+\gamma_{2} M_{t}+\gamma_{3} X P C_{t}+\gamma_{4} X T M_{t}+\gamma_{5} X O M_{t}+\gamma_{6} X O_{t}+\gamma_{7} M_{F P}+\gamma_{8} M H M_{t}\right. \\
& +\gamma_{9} M P P_{t}+\gamma_{10} M_{T} M_{t}+\gamma_{11} M \text { Ari }_{t}+\gamma_{12} M O P_{t}+\gamma_{13} Y_{t}+\gamma_{14} E R_{t}+\gamma_{15} T R F_{t}^{x}+\gamma_{16} T_{R F_{t}^{m}}^{m} \\
& \left.+\gamma_{17} \text { TOP }_{t}+\gamma_{18} \text { TOT }_{t}+\gamma_{19} B O T_{t}+\mu_{t}\right)
\end{aligned}
$$

The ARDL model for regression analysis of the variables to empirically examine the role exports, imports and its sectoral determinants in foreign trade of Pakistan is written as;

$$
\begin{aligned}
& I T_{t}=\left(\gamma_{0}+\gamma_{1} X_{t}+\gamma_{2} M_{t}+\gamma_{3} X P C_{t}+\gamma_{4} X T M_{t}+\gamma_{5} X O M_{t}+\gamma_{6} X O_{t}+\gamma_{7} M F P_{t}+\gamma_{8} M H M_{t}+\gamma_{9} M P P_{t}+\gamma_{10} M T M_{t}\right. \\
& +\gamma_{11} \text { MAgri }_{t}+\gamma_{12} M_{t} O P_{t}+\gamma_{13} Y_{t}+\gamma_{14} E R_{t}+\gamma_{15} T_{R F_{t}^{x}}+\gamma_{16} \operatorname{TRF}_{t}^{m}+\gamma_{17} T O P_{t}+\gamma_{18} T O T_{t}+\gamma_{19} B O T_{t}+\sum_{t-1}^{t=n} \beta_{0} \Delta I T_{t-1}+ \\
& \sum_{t=1}^{t=n} \gamma_{1} \Delta X_{t-1}+\sum_{t=1}^{t=n} \gamma_{2} \Delta M_{t-1}+\sum_{t=1}^{t=n} \gamma_{3} \Delta X P C_{t-1}+\sum_{t=1}^{t=n} \gamma_{4} \Delta X T M_{t-1}+\sum_{t-1}^{t=n} \gamma_{5} \Delta X O M_{t-1}+\sum_{t-1}^{t=n} \gamma_{6} \Delta X O_{t-1}+\sum_{t-1}^{t=n} \gamma_{7} \Delta M F P_{t-1}+ \\
& \sum_{t=1}^{t=n} \gamma_{8} \Delta M_{H} M_{t-1}+\sum_{t=1}^{t=n} \gamma_{9} \Delta M P P_{t-1}+\sum_{t=1}^{t=n} \gamma_{10} \Delta M T M_{t-1}+\sum_{t=1}^{t=n} \gamma_{11} \Delta M A g r i_{t-1}+\sum_{t-1}^{t=n} \gamma_{12} \Delta M O P_{t-1}+\sum_{t-1}^{t=n} \gamma_{13} \Delta Y_{t-1}+ \\
& \left.\sum_{t=1}^{t=n} \gamma_{14} \Delta E R_{t-1}+\sum_{t=1}^{t=n} \gamma_{15} \Delta T R F^{x}{ }_{t-1}+\sum_{t=1}^{t=n} \gamma_{16} \Delta T O P_{t-1}+\sum_{t=1}^{t=n} \gamma_{17} \Delta B O T_{t-1}+\sum_{t=1}^{t=n} \gamma_{18} \Delta T O T_{t-1}+\mu_{t}\right) . .
\end{aligned}
$$

The model is regressed with the help of E-Views version (9) and the important results of ARDL regression analysis is given in table (2).

To evaluate the importance of exports, imports and its determinants in international trade of Pakistan, the Auto-Regressive model has been applied for empirical analysis. The overall performance of the model is highly significant as the results obtained from the regression analysis of ARDL approach integrated in above table (2) reveals that Prob. F-stat value is (0.0000), Durbin-Watson Stat (2.065) and R-Squared value (0.9039) explaining $90 \%$ variation between dependent and explanatory variables verifying goodness of fit of the model. The DW value is greater than R-Squared value authenticating that there isn't any sign of spurious relationship in the data. The lag-length criterion is selected from Akaike and Schwarz criteria following the automatic ARDL regression lag analysis and assume the lag form as $(1,1,1,0,0,1,1,1,0,1,1,1,1,0,1,1,0,0$, $1,1)$ during regression analysis of the variables data. Exports are indispensible for economic growth of countries. Besides earning foreign exchange reserves it also fulfills the unattainable demand of the locals for products with imports. Exports also strengthen the links and relationships among the countries. Without any ambiguity a vast number of literature exits on the significant role of exports in growth of economies. This research study also aiming to empirically investigate the role of exports in foreign trade of Pakistan. The results obtained from ARDL regression analysis of the variables integrated in table (2) indicates that exports is highly significant with positive coefficient value reveals that exports plays a vital role in Pakistan's foreign trade. The estimated value of exports co-efficient is $(0.420817)$ implies that one percent increase in total exports of Pakistan will convey forty-two percent increases in overall foreign trade of Pakistan. The empirical result of this study for the impact of exports in foreign trade of Pakistan is consistent with the earlier studies 
of (Hatemi, 2002; Shirazi and Manap, 2004; Afzal, 2006; Nadeem, 2007; Mohammad, 2010; Khan and Sattar, 2010; Zada et al., 2011; Hameed et al., 2012; Hossain and Rajeb, 2012; Zakariya, 2014; Saleem and Sial, 2015).

Table: 2 ARDL Regression Results (For Evolution of Imports, Exports, Its determinants and Foreign Trade of Pakistan)

\begin{tabular}{|c|c|c|c|c|c|}
\hline Variables & Acronyms & Coefficient & Std. Error & t-Statistic & Prob. \\
\hline Constant & $\mathrm{C}$ & 0.391240 & 0.137218 & 2.851209 & 0.0413 \\
\hline Exports & $\mathrm{X}$ & 0.420817 & 0280957 & $2.285210^{*}$ & 0.0013 \\
\hline Imports & M & 0.551742 & 0.138438 & $3.985454^{*}$ & 0.0000 \\
\hline Exports & XPC & & & & \\
\hline Commodities & & 0.260681 & 0.092206 & $2.827138^{*}$ & 0.0003 \\
\hline Exports & XTM & & & & \\
\hline Manufacturing Sector & & 0.397341 & 0.148248 & $2.680234^{*}$ & 0.0037 \\
\hline Exports & $\mathrm{XOM}$ & & & & \\
\hline Manufacturing Sector & & 0.216433 & 0.116919 & $2.851126^{*}$ & 0.0023 \\
\hline Exports of Other goods & XO & 0.235885 & 0.037417 & $3.631629 *$ & 0.0000 \\
\hline Imports of food products & MFP & 0.365028 & 0.129068 & 2.828180 & 0.0025 \\
\hline Imports of Heavy Machinery & MHM & 0.276133 & 0.089630 & $3.080789 *$ & 0.0003 \\
\hline Imports of petroleum products & MPP & 0.264712 & 0.140515 & $1.883864^{* * *}$ & 0.0718 \\
\hline Imports of textile and metals & MTM & 0.263158 & 0.126206 & $2.085144^{* *}$ & 0.0446 \\
\hline Imports of agriculture & MAgri & & & & \\
\hline products and chemicals & & 0.468316 & 0.200923 & $2.330818^{* *}$ & 0.0208 \\
\hline Imports of other goods & MOP & 0.213715 & 0.075698 & $2.823224 *$ & 0.0012 \\
\hline World Income & Y & 0.425206 & 0.197622 & $2.151604^{* *}$ & 0.0385 \\
\hline Exchange Rate & ER & -0.184692 & 0.078560 & $-2.350948^{* *}$ & 0.0470 \\
\hline Export Tariffs & $\mathrm{TRF}^{\mathrm{x}}$ & -0.273650 & 0.086834 & $-3.151411^{*}$ & 0.0000 \\
\hline Trade Openness & TOP & -0.246213 & 0.174758 & -1.408874 & 0.1843 \\
\hline Terms of Trade & TOT & -0.280416 & 0.125166 & $-2.240347^{* *}$ & 0.0519 \\
\hline Balance of Trade & BOT & 0.172612 & 0.089813 & $1.943532^{* * *}$ & 0.0767 \\
\hline Error Correction Term & ECT & -0.495597 & 0.128384 & $-3.860255^{*}$ & 0.0000 \\
\hline R-squared & 0.903961 & \multicolumn{2}{|c|}{ Durbin-Watson stat } & 2.065539 & \\
\hline Adjusted R-squared & 0.882713 & \multicolumn{2}{|c|}{ Prob(F-statistic) } & 0.000000 & \\
\hline
\end{tabular}

$\left({ }^{*}\right),\left(^{* *}\right),\left(^{* * *}\right)$ showing significance at $1 \%, 5 \% \& 10 \%$ respectively.

The behavior of imports in foreign trade is tricky and confusing that may leads to gratuitous hatred towards the contribution of imports in foreign trade of countries. However, imports are the goods and services that a country can acquire from international trade which it can't produced domestically or that can accessible at a cheaper price from international market instead of domestic expensive production. Imported goods also create competition for domestic goods that not only leads to improvement in quality of domestic goods but also bring increase in varieties for consumers. Almost all of the developing countries dominantly depended on imports of goods and services. Same is the case with Pakistan, history shows its dependence on imports and except few years throughout its import bill was higher than exports since independence. This study attempts to empirically scrutinize the role of imports in foreign trade of Pakistan. The results integrated in table (2) shows considerable role of imports in foreign trade of Pakistan and reveals that one percent increase in total imports will bring an increase of fifty-five percent in overall foreign trade of Pakistan. The real statistics of 2014-154 also shows that the share of imports in foreign trade of Pakistan is fifty-eight percent approximately. The empirical results of this study and real facts and figures of statistical data of Pakistan are fairly harmonizing. A vast number of literature exits on the role and effect of imports and the empirical finding of this study for the role imports in Pakistan's foreign trade is consistent with past studies of (Musleh-Ud Din, 2004; Shirazi and Manap, 2004; Alam et al., 2010; Sulaiman and Hussain, 2012; Velnampy and Achchuthan, 2013; and Dilawar et al., 2013).

\footnotetext{
${ }^{4}$ Economic Survey of Pakistan 2014-15
} 
Exports of primary goods have vital and imperative role in foreign trade of developing and under-developed countries and considered as engine of growth for these economies. It also has an influential role in development process. Pakistan too is a developing country having lack of capital, technology and industrial structure, therefore, mostly exports primary goods to its trading partners. This study regress exports of primary goods as independent variable to empirically evaluate its role in foreign trade of Pakistan for the period 1972-2015. The results obtained from ARDL regression analysis of variables integrated in table (2) presents that the co-efficient value of Exports of primary goods in case of Pakistan is positive (0.260681) and significant as expected means that one percent increase in exports primary goods may bring an increase of twenty-six percent in overall foreign trade of Pakistan. The empirical finding of this study for exports of primary goods is consistent with the past studies of (Bahmani-Oskooee and Alse, 1993; Dutt and Ghosh, 1996; Ghatak et al., 1997; Levin and Raut, 1997; Rahman and Mustafa, 1998; Islam, 1998; Ekanayake, 1999; Dawson, 2005; Kwa and Bassoume, 2007; Sanjuan-Lopez and Dawson, 2010; Faridi, 2012). Since independence, textile sector has significantly contributed to foreign trade and growth of Pakistan via exports. That's why this study includes exports of textile as explanatory variable to empirically evaluate its importance in Pakistan's foreign trade. The ARDL regression results of the variables data integrated in table (2) shows that exports of textile sector has momentous role in foreign trade of Pakistan. The coefficient value of exports of textile sector is (0.397341) showing that one percent increase in exports of textile sector will stimulate international trade of Pakistan by thirty-nine percent. The empirical result for exports of textile and its contribution to foreign trade of Pakistan is consistent with recent studies of (Subhani et al., 2011; Zulfiqar and Kauser, 2012; Wang, 2013; Ahmad and Kalim, 2014; Nawaz and Rukhsana, 2014).

Manufacturing sector is the backbone of economies and the role of manufacturing exports is indispensable in growth and development. Both the empirical and theoretical studies highlight the importance and contribution of manufacturing exports in boosting the economic growth of different countries. Unfortunately, the manufacturing sector of Pakistan has facing sever crises especially due to energy crises since last decades. However, this study includes exports of manufacturing sector as one of independent variable to empirically examine its role in foreign trade of Pakistan. The results obtained from ARDL regression analysis of the variables integrated in table (2) found constructive and noteworthy role of manufacturing exports in Pakistan's foreign trade and reveals that one percent improvement in exports of manufacturing sector transmits approximately twenty-one percent (0.216433) enhancement in overall foreign trade of Pakistan. The ARDL empirical result for contribution of manufacturing sector exports foreign trade of Pakistan is consistent with the past studies of (Lardy, 2003; Akbar and Fatima, 2003; Alam, 2003; Cuaresma and Worz, 2005; Herzer et al., 2005; Kurt and Terzi, 2007; Parida and Sahoo, 2007; Kilavuz and Topcu, 2012). The exports of other goods and items as well as sub-groups of manufacturing like jewelry, cements etc witnessed progressive growth from previous few decades in foreign trade and in economic growth of Pakistan. The empirical results of this study obtained from ARDL regression analysis of the variables data integrated in table (2) found noteworthy and considerable role of exports of other goods and items in foreign trade of Pakistan. The results given in table (2) reveals that export of other goods and items have significant positive value (0.235885) as expected showing that one percent increase in exports of other items brings approximately twenty-three percent increase in overall foreign trade of Pakistan.

Pakistan is a developing country with rapid growth in population. It didn't fulfill intact requirements of its individuals. In order to meet food requirements of its citizen, Pakistan imports a number of food items from other countries. This study empirically attempts to examine the role of imports of food items in foreign trade of Pakistan. The ARDL regression results obtained from variables data shows that the co-efficient value of imports of food items is significant and positive as expected. The results integrated in table (2) reveals that one percent increase in imports of food items will bring an increase of approximately thirteen percent in overall foreign trade of Pakistan. The real data, facts and figures of Pakistan economy shows that during 2014- $15^{5}$ the share and value of imports of food items in total imports remained approximately eleven percent. The empirical result of this study for imports of food (primary) items is consistent with the studies of (Buzby and Unnevehr, 2004; Blalock and Veloso, 2007; Dengfeng, 2008; Qiang, 2010; Islam, 2013).

\footnotetext{
${ }^{5}$ Imports of Food items are US \$4,205.4Million, while total imports are US \$37,763.1 Million. (Source: Economic Survey of Pakistan 2014-15).
} 
Manufacturing sector plays a crucial role in economic growth and development of any country. Developed countries have abundant capital resources and known as capital intensive countries, whereas, developing countries have shortage of capital resources and mostly are labor intensive countries. The capital gap among developed and developing countries generates larger breach in growth of developed and developing countries. To offset this gap most of the developing countries imports capital goods from developed countries to enhance rapid growth and development. Pakistan also imports heavy machineries and capital goods aiming to make manufacturing sector more strong and effective and to play its role in growth and development as well as in foreign trade of Pakistan. This research study attempts to empirically examine the role of imports of capital and heavy machinery goods in foreign trade of Pakistan. The study found significant and encouraging role of capital goods imports in international trade of Pakistan as expected, showing that one percent increase in imports of capital goods will bring an increase of approximately twenty-seven percent in overall foreign trade of Pakistan. According to Economic Survey of Pakistan 2014-15, the share of imports of capital goods in overall imports during 2014-15 is about thirteen percent, while eleven percent during 2013-14. The empirical finding for the role of imports of manufacturing goods in foreign trade of Pakistan is consistent with the past studies of (Lee and Huang, 2002; Eaton and Kortum, 2001; Eaton and Kortum, 2002; Alfaro and Hammel, 2006; Alvarez and Lucas, 2007; Sun and Heshmati, 2010; Waugh, 2010; Mutreja et al., 2014).

The world economies after experiencing global financial shocks again continue to prolong the recuperation process of their restrained and uneven promptness development of their economy. But this recovery process accompanied some new challenges for world economies including downfalls in oil prices especially in 2014$15^{6}$ and expected in 2015-16 too. The gap between the demand and supply of oil imports affects the price of Petroleum products that resulted in lethargic economic growth of many countries. Though, still import of petroleum products plays an important role in foreign trade especially of oil importing and developing countries. Pakistan also imports petroleum products from different countries and fulfills eighty (80) percent of its demand by importing and twenty (20) percent from domestic petroleum production. This study attempts to examine empirically the role of imports of petroleum products in foreign trade of Pakistan including it as one of independent variable. The ARDL regression results of the variables integrated in table (2) shows encouraging and momentous affect of imports of petroleum products in foreign trade of Pakistan and reveals that one percent increase in imports of oil products will bring an increase of approximately twenty-six percent in overall foreign trade of Pakistan. The facts and figure of Pakistan economy and Bureau of Statistics of Pakistan shows that the share of imports of petroleum products is twenty-six percent in 201415 and was thirty-two percent during 2013-14. The earlier studies of (Al-Moneef, 2006; Bedi-uz-Zaman et al., 2011; Baghebo, 2012; Jawad, 2013; Baghebo and Atima, 2013; Kiani, 2013; Nazir and Qayyum, 2014; Usman et al., 2015) had also found noteworthy role of petroleum products in economic growth and in international trade of different countries.

Textile manufacturing sector of Pakistan has conventionally persisted a satisfactory performance and has reasonable contribution to growth. However, from several decades this sector has facing sever challenge of high cost and low returns. Besides the fact that textile sector of Pakistan contributed about sixty percent to total exports of Pakistan, a lot of materials and capital needed to this sector that are imported from different countries. This research study attempts to explore the role of imports of textile sector products in foreign trade of Pakistan empirically from 1972-2015, and found significant and positive role of imports of textile manufacturing in foreign trade of Pakistan. The results obtained from ARDL regression analysis reveals that one percent increase in imports of textile manufacturing goods will contribute an approximately twenty-six percent to overall foreign trade of Pakistan as integrated in table (7.5.2). The share of textile manufacturing sector shrinks 7.1 percent during 2014-15 from previous year and remained approximately Sixteen ${ }^{8}$ percent during 2014-15. The ARDL regression result for the role of imports of textile manufacturing goods in overall foreign trade of Pakistan is consistent with the earlier studies of (Dijk, 2001; Pan et al., 2004; Havrila and Gunawardana, 2006; Khan and Khan, 2010; Alam, 2011; Islam et al., 2013; and Khaliji et al., 2013).

\footnotetext{
${ }^{6}$ Economic Survey of Pakistan 2014-15.

${ }^{7}$ Economic Survey of Pakistan 2014-15.

${ }^{8}$ Economic Survey of Pakistan 2014-15
} 
Agriculture sector plays dominant role for developing countries and most of the developing countries wholly or partially depends on agriculture sector. Agriculture sector of Pakistan also has a dominant role in growth as well as in foreign trade of Pakistan since independence. From several decades, this sector experiences downwards trend and its growth ranges about twenty-percent. In order to make this sector more efficient, the government of Pakistan imports many agriculture related goods from other countries containing agri Fertilizer, agriculture related chemicals, insecticides, plastic material, Medicinal Products, hybrid seeds, fertilizers and agri-related pesticides. This research study attempts to examine empirically the role of agriculture-related products imports in foreign trade of Pakistan. The regression results obtained from regression analysis of ARDL model incorporated in table (2) found significant and positive role of imports of agri-related products in international trade of Pakistan and reveals that one percent increase in imports of agriculture related product bring an increase of approximately forty-six percent in overall Pakistan's foreign trade. The empirical result of this research study for imports of agri-related goods is consistent with the past studies of (Dorosh and Valdes, 1990; Akhtar, 2003; Dorosh and Salam, 2008; Mahmood and Akmal, 2010; Sharif et al., 2010; and Faridi, 2012).

Pakistan is a developing country and faces some disasters as well as other financial shocks that broke down the persistent growth of economy and foreign trade. From previous decades the production growth of Pakistan was severely affected due to energy crises that results an increase in imports of Pakistan. This study includes imports of other goods as independent variable to empirically assess its role in foreign trade of Pakistan. The results integrated in table (2) obtained from ARDL regression analysis of the variables indicates positive and significant role of imports of other goods in items in Pakistan's foreign trade as expected. The result reveals that one percent increase in imports of other goods will bring twenty-one percent enhancements in foreign trade of Pakistan. The real facts and figures showing the share of other items in total exports during 2014-15 is about twenty-five percent recorded from Economic Survey of Pakistan and Bureau of Statistics of Pakistan. The importance of world economies and their income distribution become a debating issue and now-a-days due to globalization has gain a considerable part in foreign trade. Those countries who have significantly adopted economic policies concurrence to the situations in international market gain considerable advantages by diverting the world demand and income through attracting the world market towards their products in order to increase their exports. However, it also noticeable that some countries especially developing countries had been suffering from augmented competitive environment of these countries. In this research study, the world income is taken as explanatory variable to empirically evaluate the role of world income in foreign trade of Pakistan. The results obtained from regression analysis of the ARDL model verifies that world income has significant and affirmative role foreign trade of Pakistan from 1972-2015. The results integrated in table (2) shows that estimator value of world trade is positive and (0.425206) reveals that one percent increase in world income may bring an increase of approximately fortytwo percent in overall foreign trade of Pakistan via exports and imports. The same result of this study for the empirical role of world income in foreign trade of Pakistan is consistent with the earlier studies of (Acemoglu and Ventura, 2002; Baldwin, 2012; Antras, 2014; Baldwin and Okubo, 2014; Baldwin, 2015).

Exchange rate is an important element/variable that affects the exports as well as imports of a country that ultimately leads to change in nature and pattern of international trade. Many countries devalue their currency to gain much fruit from foreign trade via increasing demand for their exports through lowering their exchange rate. Pakistan also devalues its currency in 1972 that brought an increase of an about forty percent at that time. In this study, the variable exchange rate is included to empirically examine its effect on international trade of Pakistan. The co-efficient value (-0.184692) of exchange rate is negative and significant indicating that one percent devaluation/depreciation in value of PKR (exchange rate) may bring an increase of eighteen percent in overall foreign trade of Pakistan. The ARDL result of this study for impact of exchange rate on foreign trade of Pakistan is consistent with the past studies of (Elbadawi, 1997; Bahmani-Oskooee, 2001; Bleaney and Greenaway, 2001; Gomes and Paz, 2005; Bouoiyour and Rey, 2005; Kemal, 2005; Waimum et al., 2008; Shahbaz et al., 2011; Shawa and Shen, 2013; Tabari and Haghight, 2014). The tariffs and exports duties play an imperative role in shaping the foreign trade of the countries. Low tariff rates boom exports that increase the foreign trade of that country. Like other countries Pakistan also adopted different tariff policies throughout history in order to increase foreign trade to achieve maximum output from exports and international trade. To empirically examine the impact of exports tariffs on foreign trade of Pakistan, this study include tariffs duties as an explanatory variable. The ARDL regression results integrated in table (2) 
shows that the co-efficient value $(-0.273650)$ of exports tariffs is negative and significant reveals that one percent decrease in exports duties may bring an increase of about twenty-seven percent in overall foreign trade of Pakistan. The empirical studies of (Bertola and Faini, 1991; Shun-Fa, 2011; Ismail and Wijnbergen, 1993; Li and Liu, 2005; Moseykin and Levchenko, 2010; Jing and Lu, 2011; Kahnamoui, 2013; and Isakova et al., 2013) had also found the significantly negative effect of exports tariffs.

Generally perceived that trade liberalization or trade openness have noteworthy effect in foreign trade as well as it generates a competitive environment for the countries to improve the quality and quantity of their products to enhance their exports (Ravallion, 2004). Mixed literature been exists regarding the role of trade openness and its possible effects. Some empirical studies support positive effect, while others observed negative whereas some studies didn't found any significant effect of trade openness or liberalization policies. Some of the economist suggests that developing countries can gain much from international trade, while other have doubtful believe on the gain from foreign trade. This study also attempts to empirically observe the connotation of trade openness on foreign trade of Pakistan. The result given in table (2) reveals that trade openness has insignificant co-efficient value and doesn't show any considerable role in foreign trade of Pakistan. The empirical studies (Dollar and Kraay, 2003; Rigobon and Rodrik, 2004; Siddiqui and Iqbal, 2005; Yucel, 2009) also didn't found any significant role of trade openness in foreign trade and in growth of different countries.

Trade balance is an important factor that clearly shows the volume of trade (exports and imports) of the countries. If a country exports is larger than imports, trade balance will be in surplus. If trade volume of exports is smaller than exports, trade balance is in deficit or negative. If volume of exports and imports are equal, trade is called balance. Most of the developing countries are suffering from deficit in their trade. Pakistan also experienced and facing continuous trade deficit except few years. This research study includes trade balance as one of the explanatory variables to assess its empirical role in foreign trade of Pakistan. The co-efficient value of trade balance $(0.172612)$ is positive and significant as expected, showing that one percent improvement in trade balance leads to an increase of approximately seventeen percent in overall international trade of Pakistan. The empirical result of this research for the role of trade balance in foreign trade of Pakistan is consistent with the past studies of (Egwaikhide, 1999; Akhtar and Malik, 2000; Sugema, 2005; mbayani, 2006; Peter and Sarah, 2006; Duasa, 2007; nienga, 2010; Waliullah et al., 2010; Mohammad, 2010; Ju et al., 2010; Levant, 2011; Saadullar and Ismail, 2012; Shawa and Shen, 2013; Abbas and Raza, 2013).

Terms of trade has gained crucial interest in determining foreign trade among the economies especially of developing countries. Huge fluctuation and instability in the price level in developing countries generate worsening terms of trade that leads to fall in foreign trade of developing countries. This research study attempts to explore the effect of terms of trade on the international trade of Pakistan. The result for terms of trade obtained from ARDL regression analysis variables integrated in table (2) that terms of trade have powerful effect in foreign trade of Pakistan. The empirical result of this study for the impact of terms of trade in foreign trade of Pakistan is consistent with the past studies of (Mendoza, 1997; Ghirmay et al., 1999; Bleaney and Greenaway, 2001; Broda and Tille, 2003; Blattman et al., 2003; Fatima, 2010). Error Correction Term (ECT) estimates the speed at which the model will return back to its original position after subsequent external shock or from disequilibrium. The behavior of ECT is also assessed and the results integrated in table (2) indicates that the value of ECT (-0.495597) is negative and significant, that means that this model can turn back at a speed of forty-nine percent to its original if suffered from any external shocks. The constant term is positive and significant; while lag of international trade has found significant positive values delivering that previous year foreign trade of Pakistan has optimistic impact on the present foreign trade.

ARDL Co-integration, Long form and Bound Testing Approach: The long-run relation of variables included in the model and their co-integration vector are also checked by applying the Bound Testing Approach, ARDL long-run and co-integration techniques. The ARDL co-integration test also confirms cointegrating vectors among the variables as shown in table (3). 
Table: 3 ARDL Co-integration Test Results

\begin{tabular}{lllll}
\hline Variable & Coefficient & Std. Error & t-Statistic & Prob. \\
\hline $\mathrm{D}(\mathrm{X})$ & 0.351208 & 0.082932 & $4.234861^{*}$ & 0.0000 \\
$\mathrm{D}(\mathrm{XPC})$ & 0.163038 & 0.045134 & $3.612310^{*}$ & 0.0001 \\
$\mathrm{D}(\mathrm{XTM})$ & 0.130497 & 0.048689 & $2.680234^{*}$ & 0.0338 \\
$\mathrm{D}(\mathrm{XOM})$ & 0.234204 & 0.126519 & $1.851126^{*}$ & 0.0889 \\
$\mathrm{D}(\mathrm{XO})$ & 0.321223 & 0.124832 & $2.573236^{*}$ & 0.0346 \\
$\mathrm{D}(\mathrm{M})$ & 0.398742 & 0.089524 & $4.453999^{*}$ & 0.0000 \\
$\mathrm{D}(\mathrm{MFP})$ & 0.174241 & 0.050923 & $3.421664^{*}$ & 0.0016 \\
$\mathrm{D}(\mathrm{MHM})$ & 0.241573 & 0.078412 & $3.080789^{*}$ & 0.0095 \\
$\mathrm{D}(\mathrm{MPP})$ & 0.186429 & 0.085023 & $2.192683^{*}$ & 0.0488 \\
$\mathrm{D}(\mathrm{MTM})$ & 0.197314 & 0.091244 & $2.162489^{*}$ & 0.0512 \\
$\mathrm{D}(\mathrm{MAGRI})$ & 0.237468 & 0.101882 & $2.330818^{*}$ & 0.0380 \\
$\mathrm{D}(\mathrm{MOP})$ & 0.167369 & 0.049787 & $3.361618^{*}$ & 0.0002 \\
$\mathrm{D}(\mathrm{Y})$ & 0.428963 & 0.105294 & $4.073937^{*}$ & 0.0000 \\
$\mathrm{D}(\mathrm{ER})$ & -0.133137 & 0.045341 & $-2.936334^{*}$ & 0.0316 \\
$\mathrm{D}(\mathrm{TRFX})$ & -0.125736 & 0.051271 & $-2.452386^{*}$ & 0.0372 \\
D(TOP) & -0.162129 & 0.115078 & -1.408874 & 0.1843 \\
$\mathrm{D}(\mathrm{BOT})$ & 0.321512 & 0.093589 & $3.435332^{*}$ & 0.0001 \\
$\mathrm{D}(\mathrm{TOT})$ & 0.163542 & 0.108072 & 1.513268 & 0.1653 \\
CointEq(-1) & -0.493640 & 0.124168 & $-3.975580^{*}$ & 0.0000 \\
\hline (*) & & &
\end{tabular}

$\left.{ }^{*}\right)$ shows co-integrating variables

To examine the long run relation between the Pakistan foreign trade and independent variables included in this study the bound testing approach is applied and the result of the test is integrated in below table (4).

Table: 4 Results of Bounds Test (Null Hypothesis: No long-run relationships exist)

\begin{tabular}{llll}
\hline Bounds Test Value & \multicolumn{3}{c}{ Critical Value Bounds } \\
\hline Test Statistic & Value & I(0) Bound & I(1) Bound \\
F-statistic & $9.803852^{*}$ & 3.61 & 2.75 \\
\hline
\end{tabular}

Critical Value is selected at $5 \%$ significance level. $\left({ }^{*}\right)$ Shows rejection of null hypothesis

The Null Hypothesis is $\gamma_{1}=\gamma_{2}=\gamma_{3}=\gamma_{4}=\gamma_{5}=\gamma_{6}=\gamma_{7}=\gamma_{8}=\gamma_{9}=\gamma_{10}=\gamma_{11}=\gamma_{12}=\gamma_{13}=\gamma_{14}=\gamma_{15}=\gamma_{16}=$ $\gamma_{17}=\gamma_{18}=\gamma_{19}=0$, assuming that there doesn't exist any long-run relation among the variables. In contrast the Alternative Hypothesis shows the existence of long run relation, that is $\gamma_{1} \neq 0, \gamma_{2} \neq 0, \gamma_{3} \neq 0, \gamma_{4} \neq 0, \gamma_{5}$ $\neq 0, \gamma_{6} \neq 0, \gamma_{7} \neq 0, \gamma_{8} \neq 0, \gamma_{9} \neq 0, \gamma_{10} \neq 0, \gamma_{11} \neq 0, \gamma_{12} \neq 0, \gamma_{13} \neq 0, \gamma_{14} \neq 0, \gamma_{15} \neq 0, \gamma_{16} \neq 0, \gamma_{17} \neq 0, \gamma_{18} \neq$ $0, \gamma_{19} \neq 0$. The hypothesis is tested through bound testing approach comparing the F-stat value with (Pesaran et al., 2001) critical values. If the F-statistics value is greater than critical value of upper bound assumed by (Pesaran et al., 2001) test, it holds to the rejection of null hypothesis. The result of bound test given in table (4) illustrates the rejection of null hypothesis and indicates the long-run relation of the variables included in the model. The Wald test is applied to verify the long run relation between dependent and independent variables of the study. The results of Wald test integrated in below table (5) confirms the long run association among the included variables and thus the findings of bound testing approach and Wald test is consistent with each other. 
Table: 5 Wald Test for Long-Run Relation

(Null Hypothesis: $\mathrm{C}(2)=\mathrm{C}(4)=\mathrm{C}(6)=\mathrm{C}(7)=\mathrm{C}(8)=\mathrm{C}(9)=\mathrm{C}(10)=\mathrm{C}(12)=\mathrm{C}(13)=\mathrm{C}(15)=\mathrm{C}(17)=\mathrm{C}(19)=\mathrm{C}(21)=\mathrm{C}(22)=$ $\mathrm{C}(24)=\mathrm{C}(25)=\mathrm{C}(26)=0)$

\begin{tabular}{lll}
\hline Test Statistic & Value & Probability \\
\hline F-statistic & $9.793628^{*}$ & 0.0000 \\
Chi-square & $83.56749^{*}$ & 0.0000 \\
\hline
\end{tabular}

$\left.{ }^{*}\right)$ shows the rejection of Null hypothesis

After confirming the long run relation between the variables we applied ARDL long form co-efficient test to empirically examine the long form behavior of the all the included behavior in brief.

Table: 6 ARDL Long forms Co-efficient Results

\begin{tabular}{lllll}
\hline Variable & Coefficient & Std. Error & t-Statistic & Prob. \\
\hline X & 0.326521 & 0.088290 & $3.698261^{*}$ & 0.0000 \\
XPC & 0.333445 & 0.133702 & $2.493941^{*}$ & 0.0269 \\
XTM & 0.261652 & 0.075527 & $3.464368^{*}$ & 0.0001 \\
XOM & 0.212504 & 0.114820 & $1.850755^{*}$ & 0.0890 \\
XO & 0.158071 & 0.061107 & $2.586774^{*}$ & 0.0226 \\
M & 0.462702 & 0.112287 & $4.120696^{*}$ & 0.0000 \\
MFP & 0.160890 & 0.067109 & $2.397430^{*}$ & 0.0322 \\
MHM & 0.253733 & 0.082387 & $3.079809^{*}$ & 0.0000 \\
MPP & 0.189027 & 0.095409 & $1.981214^{*}$ & 0.0691 \\
MTM & 0.174554 & 0.090602 & $1.926599^{*}$ & 0.0727 \\
MAGRI & 0.181644 & 0.092820 & $1.956941^{*}$ & 0.0710 \\
MOP & 0.131070 & 0.040711 & $3.219539^{*}$ & 0.0074 \\
Y & 0.563826 & 0.138399 & $4.073904^{*}$ & 0.0000 \\
ER & -0.268457 & 0.138392 & $-1.939827^{*}$ & 0.0744 \\
TRFX & -0.125781 & 0.051290 & $-2.452343^{*}$ & 0.0320 \\
TOP & -0.178048 & 0.126385 & -1.408774 & 0.1843 \\
BOT & 0.493612 & 0.143682 & $3.435448^{*}$ & 0.0000 \\
TOT & -0.122534 & 0.132684 & -0.923502 & 0.3726 \\
C & 0.239614 & 0.208148 & 1.151167 & 0.4113 \\
\hline
\end{tabular}

$\left.{ }^{*}\right)$ shows Long run relation between Dependent \& Independent Variables

The results of the ARDL long form co-efficient integrated in above table (6) indicates that exports, imports, its determinants and other trade policy variables included in this study have significantly affect the foreign trade of Pakistan in the long run. However, the study didn't found any significant effect of trade openness or trade liberalization in the long run as well as in the short run too.

Diagnostic and Stability Analysis of Model: To check the sensitivity, steadiness and goodness of fit of the model, the diagnostic and stability test are applied to check the Auto-correlation, Hetro- skedasticity, Stability, Long-run relation and co-integration among the variables as well as of the model.

Table: 7 Breusch-Godfrey Serial Correlation LM Test Result

\begin{tabular}{lll}
\hline Test Statistic & Value & Probability \\
\hline F-statistic & $1.375727^{*}$ & 0.2656 \\
Chi-square & $2.335369^{*}$ & 0.2373 \\
\hline
\end{tabular}

$\left.{ }^{*}\right)$ shows the rejection of Null hypothesis

The Breusch-Godfrey Serial Correlation LM test is applied to test the serial correlation in the model. The results integrated in table (7) shows rejection of the null hypothesis proving that the model is free from the problem of serial correlation. 
Table: 8 Breusch-Pagan-Godfrey Heteroskedasticity Test Result

\begin{tabular}{lll}
\hline Test Statistic & Value & Probability \\
\hline F-statistic & $0.526753^{*}$ & 0.9167 \\
Obs*R-squared & $20.78675^{*}$ & 0.7529 \\
\hline
\end{tabular}

$\left.{ }^{*}\right)$ shows the rejection of Null hypothesis

Though there are negligible chances of Heteroskedasticity especially in time series data, however we applied Breusch-Pagan-Godfrey Heteroskedasticity test to inspect the chances of Heteroskedasticity. The results of the Heteroskedasticity test integrated in table (8) shows that the variance among the variables is constant and thus rejects the chance of Heteroskedasticity in the model.

Table: 9 Ramsey RESET Stability Test Result

\begin{tabular}{lll}
\hline Test Statistic & Value & Probability \\
\hline t-statistic & $0.568002^{*}$ & 0.5814 \\
F-statistic & $0.322627^{*}$ & 0.5814 \\
\hline
\end{tabular}

$(*)$ shows the rejection of Null hypothesis

For stability and specification of the model, the Ramsey RESET ${ }^{9}$ Test has been applied and the results integrated in table (9) demonstrating the stability and normality of the model and acceptance of null hypothesis, that the model is stable and steer to goodness of fit.

\section{Conclusion}

Exports, imports of goods and International trade plays a vital role in the economic development of any nation and could notably be called growth locomotive. Foreign trade or International trade consists of strategies that support trade without quantitative and qualitative restrictions across international boundaries, where trading allies are permitted by the policy to have mutual benefits from the trade exactly according to the law of comparative advantage. Trade liberalization consists of policies of complete or partial removal or reduction of tariffs and non-tariff restrictions and barriers on the free exchange of capital, services and goods globally to promote "foreign trade". Today, most of the developing and developed countries approved the policy of trade liberalization through the diminution or complete eradication of trade barriers. Popular trade barriers adopted since last few decades are import and export tariffs, export subsidies, technical barriers and quotas. Time has witnessed great economic developments and sharp changes in living standards. This development can be attributed towards globalization and liberalization of international trade due to technological developments and concerted efforts to reduce trade barriers. Exports and imports (Trade) plays a key role in the economic growth and development of a country. Trade policies boost the growth of the economy which leads to the development of that country. Pakistan has also adopted many trade policies to bring Pakistan in this regard are a step towards the improvement in business environment, leads to increase in exports and economic growth. Increase in the productivity and efficient allocation of resources also brings significant change in export.

Pakistan is lacking efficiency and specialization in production resulting in higher cost per output despite intense efforts for export progression; therefore Pakistani products lacking demanded from both local and international markets due to high prices. Economic stagnation and recession leads to inefficient production process and thus lesser exports. Pakistan is facing shortage of foreign direct investment due to which new industries can't be flourished and established. Pakistan is obsessed with the dilemma that exports are concentrated with just few specific items and trading partners. Historical evidence shows that exports of Pakistan are greatly concerted in five merchandise items and to seven nations only. Furthermore, trade deficit increased due to minor value addition and exports of conventional goods. Fluctuating exchange rate due to financial instability also influence the quality and quantity of exports.

\footnotetext{
${ }^{9}$ Regression Specification error term
} 


\section{References}

Abbas, M. \& Raza, H. (2013). Effects of Trade Deficit on the Economy of Pakistan. Interdisciplinary Journal of Contemporary Research in Business, 4(11), 176-215.

Acemoglu, D. \& Ventura, J. (2002). The World Income Distribution. Quarterly Journal of Economics, 117(3), 659-94.

Achay, L. (2006). Assessing Regional Integration in North Africa. National Institute of Statistics and Applied economics, Rabat, Morocco.

Afzal, M. (2006). Causality between Exports, World Income and Economic Growth in Pakistan. International Economic Journal, 20(1), 63-77.

Ahmad, M. H., Alam, S. \& Butt, M. S. (2004). Foreign Direct Investment, Exports, and Domestic Output in Pakistan. The Pakistan Development Review, 42(4), 715-723.

Ahmad, N. \& Kalim, R. (2014). Implications of Export Competitiveness, and Performance of Textile and Clothing Sector of Pakistan: Pre and Post Quota Analysis. Pakistan Journal of Commerce and Social Sciences, 8 (3), 696-714.

Ahmed, N. (2000). Export Response to Trade Liberalization in Bangladesh: A Co-integration Analysis. Applied Economics, 32 (1), 1077-84.

Akbar, M. \& Fatima, Z. (2003), Are Exports an Engine of Growth in Pakistan? EcoMod 2003 International Conference, Istanbul, 1-35.

Akhtar, S. (2003). Is There Seasonality in Pakistan's Merchandise Exports and Imports? The Uni-variate Modelling Approach. Pakistan Development Review, 42(1), 59-75.

Akhtar, N. \& Ghani, E. (2010). Regional Integration in South Asia: An Analysis of Trade Flows Using the Gravity Model. The Pakistan Development Review, 49(2), 105-118.

Akhtar, S. \& Malik, F. (2000). Pakistan's Trade Performance VIS-À-VIS Its Major Trading Partners. The Pakistan Development Review, 39(1), 37-50.

Alam, I. (2011). Impact of Financial Crisis on Textile Industry of Pakistan: Evidence from Faisalabad. SANEI Working Paper Series No. 11-02.

Alam, M. I. (2003). Manufactured Exports, Capital Goods Imports, and Economic Growth: Experience of Mexico and Brazil. International Economic Journal, 17(4), 85-105.

Alam, M. M., Salah Udddin, M. G. \& Khan, A. S. (2010). An Empirical Study on Exports, Imports and Economic Growth of Bhutan. Indian Development Review, 8(1), 94-104.

Alfaro, L. \& Hammel, E. (2006). Capital Flows and Capital Goods. Journal of International Economics, 72, 128150.

Al-Moneef, M. (2006). The contribution of the oil sector to Arab Economic development. OFI Pamphlet Series 34.Vienna: Austria.

Alvarez, F. \& Lucas, R. J. (2007). General equilibrium analysis of the Eaton-Kortum model of international trade. Journal of Monetary Economics, 54, 1726-1768.

Awokuse, T. (2007). Causality between Exports, Imports, and Economic Growth: Evidence from Transition Economies. Economics Letters, Elsevier Publisher, 94(3), 389-395.

Azeez, B. A., Dada S. O. \& Aluko O. A. (2014). Effects of International Trade on Nigerian Economic Growth; the $21^{\text {st }}$ Century Experience. International Journal of Economics, Commerce and Management, 2(10).

Baghebo, M. (2012). Natural Resource Economics. Bayelsa: Kadmon Printing Press and Publishing House.

Baghebo, M. \& Atima, T. O. (2013).The Impact of Petroleum on Economic Growth in Nigeria. Global Business and Economics Research Journal, 2(5), 102-115.

Bahmani-Oskooee, M. (2001). Nominal and Real Effective Exchange Rates of Middle Eastern Countries and Their Trade Performance. Applied Economics, 33(1), 103-111.

Bahmani-Oskooee, M. \& Alse, J. (1993). Export Growth and Economic Growth: An Application of Cointegration and Error-Correction Modeling. Journal of Developing Areas, 27(4), 535-542.

Baldwin, R. (2012). Global Supply Chains: Why They Emerged, Why They Matters and Where They are going. CEPR Discussion Paper No. 9103.

Baldwin, R. (2015). The World Trade Organization and the Future of Multilateralism. CEPR Discussion Paper No. 11021.

Baldwin, R. \& Okubo, T. (2014). International Trade, Off-shoring and Heterogeneous Firms. Review of International Economics, 22(1), 59-72. 
Bedi-uz-Zaman, Farooq, M. \& Ullah, S. (2011). Sectoral oil consumption and economic growth in Pakistan: An ECM approach. American Journal of Scientific and Industrial Research, 2(2), 149-156.

Bertola, G. \& Faini, R. (1991). Import Demand and Non-Tariff Barriers: The Impact of Trade Liberalization. Journal of Development Economics, 34(2), 269-86.

Blalock, G. \& Veloso, F. M. (2007). Imports, Productivity Growth and Supply Chain Learning. World Development Review, 35(7), 1134-1151.

Blattman, C., Hwang, J. \& Williamson, J. G. (2003). The Terms of Trade and Economic Growth in the Periphery 1870-1983. NBER Working Paper No. 9940.

Bleaney, M. \& Greenaway, D. (2001). The Impact of Terms of Trade and Real Exchange Rate Volatility on Investment and Growth in Sub-Saharan Africa. Journal of Development Economics, 65, 491-500.

Bouoiyour, J. \& Rey, S. (2005). Exchange Rate Regime, Real Exchange Rate, Trade Flows and Foreign Direct Investments: The case of Morocco. African Review of Development, 17(2), 302-334.

Broda, C. \& Tille, C. (2003). Coping with Terms-of-Trade Shocks in Developing Countries. Current Issues in Economics and Finance, Federal Reserve Bank of New York, 9(11), 1-7.

Buzby, J. C. \& Unnevehr, L. J. (2004). Food Safety and International Trade. Agriculture Information Bulletin No. 33629, United States Department of Agriculture Economic Research Service.

Cuaresma, J. C. \& Worz, J. (2005). On Export Composition and Growth. Review of World Economics, 141(1), 3349.

Dawson, P. J. (2005). Agricultural Exports and Economic Growth in Less Developed Countries. Journal of Agricultural Economics, 33(1), 145-152.

Dengfeng, Z. (2008). The econometric analysis of the supply effects on Chinese economic growth by import trade. Contemporary Finance and Economics, 3(2), 96-101.

Dijk, M. V. (2001). The Determinants of Export Performance in Developing Countries: the Case of an Indonesian Manufacturing, Working Paper 02.01, Eindhoven Centre for Innovation Studies, the Netherlands.

Dilawar, K., Shaista, K. \& Ul-Haq, I. (2013). An Empirical Analysis of Pakistan's Bilateral Trade: A Gravity Model Approach. The Romanian Economic Journal, 4(8), 103-120.

Dollar, D. \& Kraay, A. (2003). Institutions, Trade and Growth. Journal of Monetary Economics, 50(1), 133-162.

Dorosh, P. \& Salam, A. (2008). Wheat Markets and Price Stabilization in Pakistan: An Analysis of Policy Options. Pakistan Development Review, 47(1), 71-87.

Dorosh, P. \& Valdes, A. (1990) Effects of Exchange Rate and Trade Policies on Agriculture in Pakistan. Washington, DC: IFPRI. (International Food Policy Research Institute Research Report No. 84.)

Duasa, J. (2007). Determinants of Malaysian Trade Balance: An ARDL Bound Testing Approach. Journal of Economic Cooperation, 28(3), 21-40.

Dutt, D. S. \& Ghosh, D. (1996). The Export Growth-Economic Growth Nexus: A Causality Analysis. The Journal of Developing Areas, 30(2), 167-182.

Eaton, J. \& Kortum, S. (2001). Trade in Capital Goods. European Economic Review, 45(1), 1195-1235.

Eaton, J. \& Kortum, S. (2002). Technology, Growth and Trade. Econometrica, 70, 1741-1781.

Egwaikhide, F. O. (1999). Effects of Budget Deficit on Trade Balance in Nigeria: A Stimulation Exercise. African Development Review, 11(2), 265-289.

Ekanayake, E. M. (1999). Exports and Economic Growth in Asian Developing Countries: Co-integration and Error-Correction Models. Journal of Economic Development, 24(2), 43-56.

Elbadawi, I. A. (1997). Real Exchange Rate Policy and Export Performance in Three Arab Countries. Economic Research Forum, Fourth Annual Conference on Regional Trade Finance and Labor Markets in Transition, Conference Proceedings.

Emeka, E. J., Frederick, I. \& Peter, A. (2012). Macroeconomic Impact of Trade on Nigerian Growth: An Empirical Evaluation. Research Journal of Business Management and Accounting, 1(4), 79-83.

Faridi, M. Z. (2012). Contribution of Agricultural Exports to Economic Growth in Pakistan. Pakistan Journal of Commerce and Social Science, 6(1), 133-146.

Fatima, N. (2010). Analyzing the Terms of Trade Effect for Pakistan. PIDE Working Papers 2010: 59.

Filippini, C. \& Molini, V. (2003). The Determinants of East Asian Trade Flows: A Gravity Equation Approach. Journal of Asian Economics, 14(5), 695-711.

Ghatak, S., Milner, C. \& Utkulu, U. (1997). Exports, Export Composition and Growth: Co-integration and Causality Evidence for Malaysia. Applied Economics, 29(2), 213-223. 
Ghirmay, T. C., Sharma, S. \& Grabowski, R. (1999). Export Instability, Income Terms of Trade Instability and Growth: Causal Analyses. The Journal of International Trade and Economic Development: An International and Comparative Review, 8(2), 209-229.

Gomes, F. A. R. \& Paz, L. S. (2005). Can real exchange rate devaluation improve trade balance? The 1990-1998 Brazilian case. Applied Economics Letters, 12, 525-528.

Hameed, I., Iqbal, A. \& Devi, K. (2012). Relationship between Exports and Economic Growth of Pakistan. European Journal of Social Sciences, 32(3), 453-460.

Hatemi J. A. (2002). Export Performance and Economic Growth Nexus in Japan: A bootstrap approach. Japan and the World Economy, 14(1), 25-33.

Havrila, J. \& Gunawardana, P. (2006). Determinants of Export Supply of the Australian Textiles Industry. Economic Analysis \& Policy, 36(1-2), 45-59.

Herzer, D., Lehmann, F. N. \& Siliverstovs, B. (2005). Export-Led Growth in Chile: Assessing the Role of Export Composition in Productivity Growth. America Institute for Economic Research, Germany, 1-30.

Hossain, M. M. \& Rajeb, M. (2012). Toward Bracketing the Seasonal Export-Import of Bangladesh: A Time Series based Analytical Approach. Terengganu International Finance and Economics Journal, 2(2), 103-117.

Iacovoiu, V. B. (2013). Perspectives on Romania's Economic Growth through the Evolution of Direct Investment Flows. Economic Insights - Trends and Challenges, 2(1), 84-95.

Isakova, A., Koczan, Z. \& Plekhanov, A. (2013). How Much Do Tariffs Matter? Evidence from the Custom Unions of Belarus, Kazakhstan and Russia. EBRD Working Paper No. 154,1-22.

Islam, M. N. (1988). Export Expansion and Economic Growth: Testing for Co-integration and Causality. Applied Economics, 30(3), 415-425.

Islam, M. M., Khan, A. M. \& Islam, M. M. (2013). Textile Industries in Bangladesh and Challenges of Growth. Research Journal of Engineering Sciences, 2(2), 31-37.

Ismail, A. \& Wijnbergen, V. S. (1993). Export Incentives, Exchange Rate Policy and Export Growth in Turkey. The Review of Economics and Statistics, 75(1), 128-133

Javed, H. Z., Qaisar, I., Mushtaq, A., Saif-Ullah. \& Iqbal, A. (2012). Effects of International Trade on Economic Growth: A Case Study of Pakistan. International journal of Academic Research in Progressive Education and Development, 1(2), 103-113.

Jawad, M. (2013) Oil Price Volatility and its Impact on Economic Growth in Pakistan. Journal of Finance and Economics, 1(4), 62-68.

Jing, M. \& Lu, Y. (2011). Free Trade or Protection: A Literature Review on Trade Barriers. Research in World Economy, 2(1), 69-76.

Ju, J., Wu, Y. \& Zeng, L. (2010). The Impact of Trade Liberalization on the Trade Balance in Developing Countries. IMF Staff Papers, 57(2), 427-49.

Kahnamoui, F. (2013). Do Trade Restrictions or Openness Affect Economic Growth Differently in the Presence of Export Credits? Business and Economics Journal, 69, 1-11.

Kemal, M. A. (2005). Exchange Rate Instability and Trade: The Case of Pakistan. Pakistan Institute of Development Economics. Islamabad: Research Report no. 186.

Khan, A. A. \& Khan, M. (2010). Pakistan Textile Industry Facing New Challenges. Research Journal of International Studies, 14, 21-29.

Khan, A. E. R. \& Sattar, R. (2010). Trade Growth and Poverty: A Case of Pakistan. Pakistan Journal of Social Science, 4(2), 173-184.

Khaliji, B. A., Jaffari, S., Shahzad, A. \& Mehtab, M. (2013). Role of Textile Sector in Domestic Development. Business Management Dynamics, 2(10), 14-27.

Kiani, A. (2013) Impact of High Oil Prices on Pakistan's Economic Growth. International Journal of Business and Social Science, 2(17), 209-216.

Kilavuz, E. \& Topcu, A. B. (2012). Export and Economic Growth in the Case of the Manufacturing Industry: Panel Data Analysis of Developing Countries. International Journal of Economics and Financial Issues, 2(2), 201-215.

Kurt, S. \& Terzi, H. (2007), Relation between Foreign Trade, Productivity and Economic Growth. Journal of Economics and Administrative Sciences, 21(1), 25-46.

Kwa \& Bassoume. (2007). Exploring the Linkages between Agricultural Exports and Sustainable Development. Ecofair trade dialogue [Discussion Paper], 2, 1-38. 
Lardy, N. R. (2003). Trade Liberalization and Its Role in Chinese Economic Growth. Institute for International Economics, International Monetary Fund, Washington, D.C.

Lee, C. \& Huang, B. (2002). The Relationship between Exports and Economic Growth in East Asian Countries: A Multivariate Threshold Autoregressive Approach. Journal of Economic Development, 27(2), 45-68.

Levant, K. (2011). An Empirical Model for the Turkish Trade Balance: New Evidence from ARDL Bound Testing Analyses. MPRA Paper No. 32550.

Levin, A. \& Raut, L. K. (1997). Complementarities between Exports and Human Capital: Evidence from the Semi-Industrialized Countries. Economic Development and Cultural Change, 46(1), 155-174.

Li, X. \& Liu, X. (2005). Foreign Direct Investment and Economic Growth: An Increasingly Endogenous Relationship. World Development, 33(3), 393-407.

Mahmood, M. A. \& Akmal, N. (2010). Impact o Trade Liberalization on Agriculture in Pakistan: A REVIEW. Journal of Agriculture Resource, 48(1), 1-11.

Martinez-Zarzoso, I. \& Nowak-Lehmann, F. (2003). Augmented Gravity Model: An Empirical Application to Mercosur-European Union Trade Flows. Journal of Applied Economics, 6(2), 291-316.

Mbayani, S. (2006). Determinants of trade balance in Tanzania, A research paper towards the fulfillment of masters of Arts degree in economic policy management (PPT), Makerere University.

Mendoza, E. G. (1997). Terms-of-Trade Uncertainty and Economic Growth. Journal of Development Economics, 54,323-356

Mohammad, D. S. (2010). Determinant of Balance of Trade: Case Study of Pakistan. European Journal of Scientific Research, 41(1), 13-20.

Moseykin, N. Y. \& Levchenko, V. I. (2010). The Impact of Agricultural Import Tariff on Economic Growth: Evidence from Mercosur Countries. Chinese Business Review, 13(3), 137-153.

Musleh-Ud, D. (2004). Exports, Imports, and Economic Growth in South Asia: Evidence using a Multivariate Time Series Framework. Pakistan Development Review, 43(2), 105-124.

Mutreja, P., Ravikumar, B. \& Sposi, M. (2014). Capital Goods Trade and Economic Development. Working Paper No. 2014-012A.

Nadeem, M. (2007). Pakistan Agricultural Export Performance in the Light of Trade Liberalization and Economic Reforms. [Working Papers] 45854, University of Baluchistan, Commerce Department.

Nawaz, A. \& Rukhsana, K. (2014). Implications of Export Competitiveness, and Performance of Textile and Clothing Sector of Pakistan: Pre and Post Quota Analysis. Pakistan Journal of Commerce and Social Sciences, 8(3), 696-714.

Nazir, S. \& Qayyum, A. (2014). Impact of Oil Price and Shocks on Economic Growth of Pakistan: Multivariate Analysis. MPRA Paper No. 55929.

Nienga, E. (2010). The Determinants of Trade Balance in Kenya; An Empirical Analysis; 1970-2010.

Pan, S., Somwaru, A. \& Tuan, F. (2004).China's Role in World Cotton and Textile Markets. 7th Annual Conference on Global Economic Analysis, Washington, DC

Parida, P. C. \& Sahoo, P. (2007), Export-led Growth in South Asia: A Panel Co-integration Analysis. International Economic Journal, 21(2), 155-175.

Pesaran, M. H., Shin, Y. \& Smith, R. J. (2001). Bounds Testing Approaches to the Analysis of Level Relationships. Journal of Applied Economy, 16(1), 289-326.

Peter W. \& Sarah T. (2006). The Trade Balance Effects of U.S. Foreign Direct Investment in Mexico. American Economic Journal, 27(1), 24-39.

Qiang, S. (2010). The Research on the Relationship Between Import Trade Structure and Economic Growth in China. IZA working Paper, 187-191.

Rahman, M. \& Mustafa, M. (1998). Dynamics of Real Exports and Real Economic Growth in 13 Selected Asian Countries. Journal of Economic Development, 22(2), 81-95.

Ravallion, M. (2004). Looking Beyond Averages in the Trade and Poverty Debate. Policy Research Working Paper No. 3461, The world Bank.

Rigobon, R. \& Rodrik, D. (2004). Rule of Law, Democracy, Openness, and Income: Estimating the Interrelationships. NBER Working Papers No. 10750.

Saadullar, M. Z. k. \& Ismail, M. H. (2012). Determinants of Trade Balance of Bangladesh: A Dynamic Panel Data Analysis. Bangladesh Development Studies, 35(2), 43-52.

Saleem, A. \& Sial, M. H. (2015). Exports-Growth Nexus in Pakistan: Co-integration and Causality Analysis. Pakistan Economic and Social Review, 53(1), 17-46. 
Sanjuan-Lopez, A. I. \& Dawson, P. J. (2010). Agricultural Exports and Economic Growth in Less Developed Countries: A Panel Co-integration Approach. Journal of Agricultural Economics, 61(3), 565-583.

Santos-Paulino. \& Thirlwall, A. P. (2004). The Impact of Trade Liberalization on Exports, Imports, and the Balance of Payments of Developing Countries. Economic Journal, 114(1), 50-72.

Shahbaz, M., Jalil, A. \& Islam, F. (2011). Real Exchange Rate Changes and Trade Balance in Pakistan: A Revisit. Munich Personal RePEc Archive, Paper No. 27631.

Sharif, S., Javed, S. M., Abbas, A. \& Hassan, S. (2010). Impact of WTO's Trade Liberalization on Selected Food Crops in Pakistan. Pakistan Development Review, 47(4), 547-563.

Shawa, M. J. \& Shen, Y. (2013). Analysis of the Determinants of Trade Balance: Case study of Tanzania. International Journal of Business and Economics Research, 2(6), 134-141.

Shirazi, S. N. \& Manap, T. A. (2004). Export-Led Growth Hypothesis: Further Econometric Evidence from Pakistan. Pakistan Development Review, 43(4), 563-581.

Siddiqui, H. A. \& Iqbal, J. (2005). Impact of Trade Openness on Output Growth for Pakistan: An Empirical Investigation. Market Forces, 1(1), 1-9.

Subhani, M., Imtiaz, Amber, O. \& Khokhar, R. (2011). The New Version of Gravity Model in Explaining Bilateral Trade; a Comparative Study for Developed and Developing Nations. Journal of Euro Economica, 28 (2), 41-50.

Sugema, I. (2005). The Determinants of Trade Balance and Adjustment to the Crisis in Indonesia. Centre of International Economic Studies (CIES), Discussion Paper No. 0508.

Shun-Fa, L. (2011). Tariff, growth and welfare. Review of International Economics, 19(2), 260-276.

Sulaiman, M. D. \& Hussain, A. (2012). The Causal Relationship between Openness and Economic Growth: Empirical Evidence In Case Of Pakistan. Pakistan Journal of Commerce and Social Science, 6(2), 382391.

Sun, P. \& Heshmati, A. (2010). International Trade and its effects on Economic Growth in China. IZA, Discussion Paper No. 5151.

Tabari, Y. A. N. \& Haghight, S. (2014). Iran's Regional Trade and Real Exchange Rate (Gravity Panel Data Models). International Journal of Economy, Management and Social Sciences, 3(1), 113-117

Usman, A., Ikemefuna, M. \& Fatimah, A. (2015). Evidence of Petroleum Resources on Nigerian Economic Development. Business and Economic Journal, 6(2), 1-4.

Velnampy, T. \& Achchuthan, S. (2013). Export, Import and Economic Growth: Evidence from Sri Lanka. Journal of Economics and Sustainable Development, 4(9), 1-10.

Wacziarg, R. \& Welch, H. K. (2003). Trade Liberalization and Growth: New Evidence. NBER Working Paper No. 10152.

Wai-mum, H., Yuen-ling, N. G. \& Tan, G. M. (2008). Real Exchange Rate and Trade Balance Relationship: An Empirical Study on Malaysia. International Journal of Business and Management, 3(8), 130-139.

Waliullah, M., Mehmood, K. K., Rehmatullah, K. \& Wekeel, K. (2010).The Determinants of Pakistan's Trade Balance: An ARDL Co integration Approach. The Lahore Journal of Economics, 15(1), 1-26.

Wang, X. (2013). The determinants of textile and apparel export performance in Asian countries. Graduate Theses and Dissertations, Paper 13642.

Waugh, E. M. (2010). International Trade and Income Differences. American Economic Review, 100(5), 20932124.

Yanikkaya, H. (2003). Trade Openness and Economic Growth: A Cross Country Empirical Investigation. Journal of Development Economics, 72(1), 57-89.

Yucel, F. (2009). Causal Relationships between Financial Development, Trade Openness and Economic Growth: The Case of Turkey. Journal of Social Sciences, 5(1), 33-42.

Zada, N., Muhammad, M. \& Bahadur, K. (2011). Determinants of Exports of Pakistan: A Country-wise Disaggregated Analysis. The Pakistan Development Review, 50(4), 715-732.

Zakaria, M. (2014). Effects of Trade Liberalization on Exports, Imports and trade Balance in Pakistan; A Time Series Analysis. Prague Economic Paper, 1(1), 121-139.

Zaman, K., Qaiser, A., Adnan, K. \& Zahid, A. (2010). Empirical Evidence of Trade Integration between Pakistan and Turkey (A Gravity Approach). Journal of Managerial Sciences, 4(2), 106-114.

Zulfiqar, K. \& Kausar, R. (2012). Trade Liberalization, Exchange Rate and Export Growth in Pakistan. Far East Journal of Psychology and Business, 9(3), 32-47. 